\title{
THE LIMITS OF DETECTABLE CEREBRAL PERFUSION BY TRANSCRANIAL DOPPLER SONOGRAPHY IN NEONATES UNDERGOING DEEP HYPOTHERMIC LOW-FLOW CARDIOPULMONARY BYPASS
}

\author{
A. Andrew Zimmerman, MD \\ Frederick A. Burrows, MD \\ Richard A. Jonas, $\mathrm{MD}^{\mathrm{b}}$ \\ Paul R. Hickey, MD
}

\begin{abstract}
Objective: Neurologic morbidity including seizures, abnormal neurologic function, and delayed psychomotor development continue to be significant problems for some patients undergoing operations for congenital heart disease, particularly for those subjected to deep hypothermic circulatory arrest. The technique of low-flow cardiopulmonary bypass has been advocated to decrease the incidence of neurologic sequelae. Our study examined the limits of detectable blood flow in the middle cerebral artery during low-flow cardiopulmonary bypass in 28 neonates undergoing the arterial switch procedure. Methods: Cerebral blood flow velocity was measured noninvasively in the M1 segment of the middle cerebral artery with a $2 \mathrm{MHz}$ range-gated pulsed-wave transcranial Doppler sonographic probe that was placed over the left temporal window. As part of the initiation of a planned period of deep hypothermic circulatory arrest, the cardiopulmonary bypass flow rate was decreased in stages to five low-flow rates $(50,40,30,20$, and $10 \mathrm{ml} / \mathrm{kg}$ per minute). After a period of stabilization, cerebral blood flow velocities were recorded at each of the five low-flow rates and reported as a percentage of baseline. Results: All 28 neonates had detectable perfusion in the middle cerebral artery at flow rates of $30 \mathrm{ml} / \mathrm{kg}$ per minute or higher. At flows of 20 and $10 \mathrm{ml} / \mathrm{kg}$ per minute, one and eight, respectively, of the 28 neonates had no detectable perfusion in the middle cerebral artery. Conclusions: Our data show that cerebral perfusion can be detected by transcranial Doppler sonography in the middle cerebral artery in some neonates at bypass pump flows as low as $10 \mathrm{ml} / \mathrm{kg}$ per minute. However, when transcranial Doppler sonography was used in our patient population, a minimum bypass flow rate of $30 \mathrm{ml} / \mathrm{kg}$ per minute was needed to detect cerebral perfusion in all neonates. (J Thorac Cardiovasc Surg 1997;114:594-600)
\end{abstract}

D espite advances in cardiac surgery, anesthesia, and cardiopulmonary bypass (CPB), neurologic morbidity remains a significant complication of operations for congenital heart disease. ${ }^{1-4}$ Recent clin-

From the Cardiac Anesthesia Service, Department of Anesthesia, ${ }^{a}$ and the Department of Cardiac Surgery, ${ }^{\text {b Children's }}$ Hospital and Harvard Medical School, Boston, Mass.

A portion of this work was presented at the Annual Meeting of the Society for Pediatric Anesthesia, February 17, 1996.

Supported by National Institutes of Health grant HL-41786.

Received for publication Feb. 4, 1997; revisions requested March 17, 1997; revisions received May 30, 1997; accepted for publication May 30, 1997.

Address for reprints: A. Andrew Zimmerman, MD, Department of Anesthesia, St. Louis Children's Hospital, No. 1 Children's Place, St. Louis, MO 63110.

Copyright $(\mathcal{C} 1997$ by Mosby-Year Book, Inc.

$0022-5223 / 97 \$ 5.00+0 \quad \mathbf{1 2 / 1 / 8 3 6 2 3}$ ical studies have suggested that low-flow CPB may result in fewer neurologic sequelae than deep hypothermic circulatory arrest (DHCA) in neonatal heart surgery. ${ }^{5,6}$ In the Boston Circulatory Arrest Study, neonates who undrwent cardiac operations with DHCA as the predominant technique were more likely to have postoperative seizures than were neonates in whom low-flow CPB was the predominant technique. ${ }^{5}$ In a 1-year follow-up, patients in the DHCA group had lower psychomotor development scores. ${ }^{6}$ In these studies, a CPB flow rate of 50 $\mathrm{ml} / \mathrm{kg}$ per minute was used. Few studies have examined the lower limits of low-flow CPB. In a sheep model, a CPB flow rate as low as $10 \mathrm{ml} / \mathrm{kg}$ per minute has been shown to preserve intracellular $\mathrm{pH}$ and high-energy phosphates levels. ${ }^{7}$

The measurement of cerebral blood flow velocity by transcranial Doppler sonography (TCD) has 
been shown to correlate with cerebral blood flow as measured by tracer washout techniques. ${ }^{8,9}$ In a clinical study, Jonassen, Quaegebeur, and Young, ${ }^{10}$ using TCD, demonstrated detectable cerebral perfusion in children when the $\mathrm{CPB}$ pump flows were in the range of 25 to $50 \mathrm{ml} / \mathrm{kg}$ per minute. In other reports, cerebral perfusion was not detected reliably in neonates by TCD during low-flow CPB. ${ }^{11}$ However, these studies may have been flawed by the use of low-pass filters on the TCD instrument. These filters have a lower threshold of 3 to $5 \mathrm{~cm} / \mathrm{sec}$; therefore very low flow velocity may be present but not detected. The effects of extremely low flow rates in children have not been clinically studied. The purpose of this study was to determine the lower limits of CPB flow rate necessary to provide cerebral perfusion detectable by TCD in the middle cerebral artery (MCA) during low-flow CPB using a monitor in which the filters had been disabled.

\section{Methods}

With institutional approval and informed parental consent, 28 neonates undergoing the arterial switch procedure for d-transposition of the great vessels were studied. These 28 neonates were a subset of the patients whose neurologic outcome was previously reported. ${ }^{5,6}$

Anesthesia was induced with fentanyl 20 to $50 \mu \mathrm{g} / \mathrm{kg}$, and neuromuscular blockade was obtained with pancuronium 0.1 to $0.15 \mathrm{mg} / \mathrm{kg}$. After nasotracheal intubation, controlled mechanical ventilation was used to ventilate the lungs with an air-oxygen mixture to maintain normocarbia. Anesthesia was maintained with supplemental doses of fentanyl and pancuronium. A total of 75 to 100 $\mu \mathrm{g}$ of fentanyl was used in all neonates. A radial arterial catheter was inserted for measurement of systemic arterial pressure and intermittent blood sampling. Rectal, tympanic, and esophageal temperatures were monitored continuously.

Cerebral blood flow velocity was used as an index of cerebral perfusion and was measured noninvasively with a $2 \mathrm{MHz}$, range-gated, pulsed-wave TCD sonographic probe that was placed over the left or right temporal window (EME TC 2000S, Carolina Medical Electronics Inc., King, N.C.). The low-pass filters were disabled in this TCD instrument. The cerebral blood flow velocity was measured in the M1 segment of the MCA. To ensure a reproducible window, we aimed the probe so that the MCA signal was accompanied by a retrograde flow signal from the A1 segment of the anterior cerebral artery. Once an acceptable waveform was achieved, the probe position was secured with an adhesive and a protective cage was placed over the transducer.

After anticoagulation with heparin, nonpulsatile CPB was established with a standard roller pump (Cinco, Wakefield, Mass.) and a VPCML membrane oxygenator (Cobe Laboratories, Inc., Denver, Colo.). The CPB circuit was primed with packed red blood cells, $5 \%$ albumin, and an electrolyte solution (Normosol; Abbott Laboratories,
Table I. Demographic data

\begin{tabular}{lc}
\hline Age (days) & $7 \pm 6$ \\
Weight $(\mathrm{kg})$ & $3.5 \pm 0.4$ \\
Male & 21 \\
Female & 7 \\
\hline
\end{tabular}

Values are given as mean \pm standard deviation.

North Chicago, Ill.) to maintain a hematocrit value of $22 \%$ to $30 \%$ during CPB. All patients were cooled until all temperatures were less than $18^{\circ} \mathrm{C}$ over 16 to 20 minutes. Alpha-stat acid-base management was used during hypothermic CPB to maintain an uncorrected arterial carbon dioxide tension at $40 \mathrm{~mm} \mathrm{Hg}$.

Throughout the study, mean arterial pressure (MAP), cerebral blood flow velocity, and esophageal, rectal, and tympanic temperatures were measured and recorded continuously. Baseline measurements were taken after induction but before incision at normocarbia. Arterial blood gases were measured every 15 minutes.

In all cases a period of DHCA was anticipated during the procedure. Before the start of DHCA, the CPB flow rate was decreased from $150 \mathrm{ml} / \mathrm{kg}$ per minute $(2.4 \mathrm{~L} / \mathrm{min}$ per square meter) to $50 \mathrm{ml} / \mathrm{kg}$ per minute $(0.8 \mathrm{~L} / \mathrm{min}$ per square meter). Once a stable flow of $50 \mathrm{ml} / \mathrm{kg}$ per minute was achieved for at least 5 minutes, the CPB flow rate was decrementally decreased in steps of $10 \mathrm{ml} / \mathrm{kg}$ per minute until zero flow was reached and DHCA was begun $(50,40$, $30,20,10$, and $0 \mathrm{ml} / \mathrm{kg}$ per minute). At each decremental flow rate, CPB flow rate was held stable for 60 to 120 seconds to assure development of a steady state. Previous experience has demonstrated that a steady state is achieved in this time frame. Cerebral blood flow velocities were then recorded at each of the five low-flow rates and reported as a percentage of baseline measurements taken after induction.

Data analysis. Data are presented as the mean \pm the standard deviation. Pearson's correlation coefficient was used to measure the relationship between MAP and CPB pump flow rate. Nonpaired Student's $t$ tests were used to compare MAP in groups with and without detectable cerebral blood flow by TCD. One-way analysis of variance for repeated measures followed by a Newman-Keuls test was used to compare absolute velocities and arterial pressures at different CPB pump flow rates. Statistical significance was accepted as $p<0.05$.

\section{Results}

Twenty-eight neonates were studied. The demographic data are reported in Table I. The temperature and end-tidal carbon dioxide data are presented in Table II. Cerebral blood flow velocities are reported as a percentage of baseline. Baseline was determined to be the anesthetized state before incision. Table III shows the mean velocities and the MAPs at each of the low-flow perfusion rates. A significant difference was noted in absolute velocities and MAPs at all five flow rates. All 28 patients had detectable perfusion in the MCA at flow rates 
Table II. Temperature and carbon dioxide data

\begin{tabular}{ll}
\hline Baseline arterial carbon dioxide $(\mathrm{mm} \mathrm{Hg})$ & $34.6 \pm 9.4$ \\
Arterial carbon dioxide at low-flow & $37.3 \pm 4.5$ \\
$\quad \mathrm{CPB}(\mathrm{mm} \mathrm{Hg})$ & \\
Low-flow CPB esophageal temperature $\left({ }^{\circ} \mathrm{C}\right)$ & $14.5 \pm 1.8$ \\
Low-flow CPB rectal temperature $\left({ }^{\circ} \mathrm{C}\right)$ & $14.8 \pm 1.0$ \\
Low-flow CPB tympanic temperature $\left({ }^{\circ} \mathrm{C}\right)$ & $14.8 \pm 1.2$
\end{tabular}

Values are given as mean \pm standard deviation.

of $30 \mathrm{ml} / \mathrm{kg}$ per minute or higher. At a flow rate of $20 \mathrm{ml} / \mathrm{kg}$ per minute, one of the 28 patients had no detectable perfusion in the MCA. At a flow rate of $10 \mathrm{ml} / \mathrm{kg}$ per minute, only 20 of the 28 patients $(71.4 \%$ ) had detectable perfusion in the MCA (Fig. 1). When zero flow was reached, TCD-detectable MCA perfusion ceased in these patients within 10 seconds. The relationship between MAP and CPB flow rate in individual patients is shown in Fig. 2. Box plots of the relationship between MAP and velocity with $\mathrm{CPB}$ pump flow rates are shown in Figs. 3 and 4. All patients with an MAP of $19 \mathrm{~mm} \mathrm{Hg}$ or greater, regardless of pump flow rate, had detectable cerebral perfusion by TCD, but correlation between MAP and CPB pump flow rates was minimal $\left(r^{2}=0.29\right)$. The MAP of all 28 patients at a flow rate of $10 \mathrm{ml} / \mathrm{kg}$ per minute was $13.7 \pm 5.5 \mathrm{~mm} \mathrm{Hg}$, but when the patients with detectable perfusion in the MAP by TCD were compared with those without detectable perfusion, the MAPs were $15.0 \pm 5.3$ and $10.3 \pm 4.3 \mathrm{~mm} \mathrm{Hg}$, respectively $(p=0.04)$.

\section{Discussion}

Our study examined a range of CPB flow rates from 150 to $10 \mathrm{ml} / \mathrm{kg}$ per minute in neonates at $18^{\circ} \mathrm{C}$. All 28 patients in our study had detectable MCA perfusion at a CPB flow rate of $30 \mathrm{ml} / \mathrm{kg}$ per minute or higher. A CPB flow rate of $20 \mathrm{ml} / \mathrm{kg}$ per minute resulted in detectable cerebral perfusion in the MCA in 27 of the $28(94 \%)$ patients. When a CPB flow rate of $10 \mathrm{ml} / \mathrm{kg}$ per minute was used, eight of the 28 patients $(28.6 \%$ ) had no detectable MCA perfusion.

During $\mathrm{CPB}$, the relationship between perfusion of the cerebral microcirculation and perfusion in the large cerebral arteries such as the MCA is complex and not well understood. This study focused on flow velocity in the MCA as a necessary, but not sufficient, condition for perfusion of the cerebral microcirculation supplied by the MCA. Inasmuch as flow velocity in other great arteries was not measured, this study does not address whether levels of CPB flow adequate to provide TCD-measurable perfusion in the MCA
Table III. Cerebral blood flow velocity data

\begin{tabular}{|c|c|c|c|}
\hline \multirow[b]{2}{*}{$C P B$ pump flow rate } & \multicolumn{2}{|c|}{$\begin{array}{c}\text { Cerebral blood flow } \\
\text { velocity }\end{array}$} & \multirow[b]{2}{*}{$\begin{array}{c}M A P \\
(m m H g \pm S D)\end{array}$} \\
\hline & $\begin{array}{l}\text { Percent of } \\
\text { baseline }\end{array}$ & $\begin{array}{l}\text { Absolute } \\
\text { velocity } \\
(\mathrm{cm} / \mathrm{sec})\end{array}$ & \\
\hline $\begin{array}{l}50 \mathrm{ml} / \mathrm{kg} \text { per minute } \\
0.79 \mathrm{~L} / \mathrm{min} \text { per square } \\
\text { meter }\end{array}$ & $34.6 \pm 9.4$ & $7 \pm 3 \doteqdot$ & $25.2 \pm 8.0 \%$ \\
\hline $\begin{array}{l}40 \mathrm{ml} / \mathrm{kg} \text { per minute } \\
0.63 \mathrm{~L} / \mathrm{min} \text { per square } \\
\text { meter }\end{array}$ & $37.3 \pm 4.5$ & $6 \pm 3 \%$ & $23.3 \pm 7.1 \ddagger$ \\
\hline $\begin{array}{l}30 \mathrm{ml} / \mathrm{kg} \text { per minute } \\
0.48 \mathrm{~L} / \mathrm{min} \text { per square } \\
\text { meter }\end{array}$ & $14.5 \pm 1.8$ & $5 \pm 2 \ddagger$ & $20.1 \pm 6.5+$ \\
\hline $\begin{array}{l}20 \mathrm{ml} / \mathrm{kg} \text { per minute } \\
0.32 \mathrm{~L} / \mathrm{min} \text { per square } \\
\text { meter }\end{array}$ & $14.8 \pm 1.0^{*}$ & $4 \pm 2 *$ & $16.9 \pm 5.9 \neq$ \\
\hline $\begin{array}{l}10 \mathrm{ml} / \mathrm{kg} \text { per minute } \\
0.16 \mathrm{~L} / \mathrm{min} \text { per square } \\
\text { meter }\end{array}$ & $14.8 \pm 1.2 \dagger$ & $2 \pm 2 \uparrow$ & $13.5 \pm 5.5$ † \\
\hline
\end{tabular}

Values are given as mean \pm standard deviation.

${ }^{*}$ Only 27 of the 28 patients included. One had no detectable perfusion. fOnly 20 of the 28 patients included. Eight had no detectable perfusion. $¥$ Statistically significant differences in MAP and cerebral blood flow velocity between all five CPB pump flow rates.

also provide measurable perfusion in the other arteries of the circle of Willis, let alone perfusion of the microcirculation supplied by those arteries.

To address the issue of global perfusion of the cerebral microcirculation and its relationship to $\mathrm{CPB}$ flow rate during hypothermic low-flow $\mathrm{CPB}$, a number of animal studies have examined the lower limit of cerebral blood flow necessary for the brain to maintain intracellular substrate levels at hypothermic temperatures. Swain and colleagues ${ }^{7}$ used phosphorus nuclear magnetic spectroscopy in adolescent sheep and determined that a CPB flow rate of $10 \mathrm{ml} / \mathrm{kg}$ per minute (approximately $0.3 \mathrm{~L} / \mathrm{min}$ per square meter) preserved high-energy phosphates and intracellular $\mathrm{pH}$. A CPB flow rate of $5 \mathrm{ml} / \mathrm{kg}$ per minute (approximately $0.15 \mathrm{~L} / \mathrm{min}$ per square meter) or DHCA resulted in a progressive decline in high-energy phosphates and intracellular $\mathrm{pH}$. Fox, Blackstone, and Kirklin ${ }^{12}$ used microspheres to examine regional and total cerebral blood flow in monkeys. They found that oxygen consumption by the brain remained unchanged despite decreasing $\mathrm{CPB}$ flow rate to $0.5 \mathrm{~L} / \mathrm{min}$ per square meter (approximately $35 \mathrm{ml} / \mathrm{kg}$ per minute). Miyamoto and coworkers ${ }^{13}$ examined arterial-sagittal sinus blood flow in dogs during $\mathrm{CPB}$ at $20^{\circ} \mathrm{C}$. They concluded that the optimal $\mathrm{CPB}$ flow rate at $20^{\circ} \mathrm{C}$ 


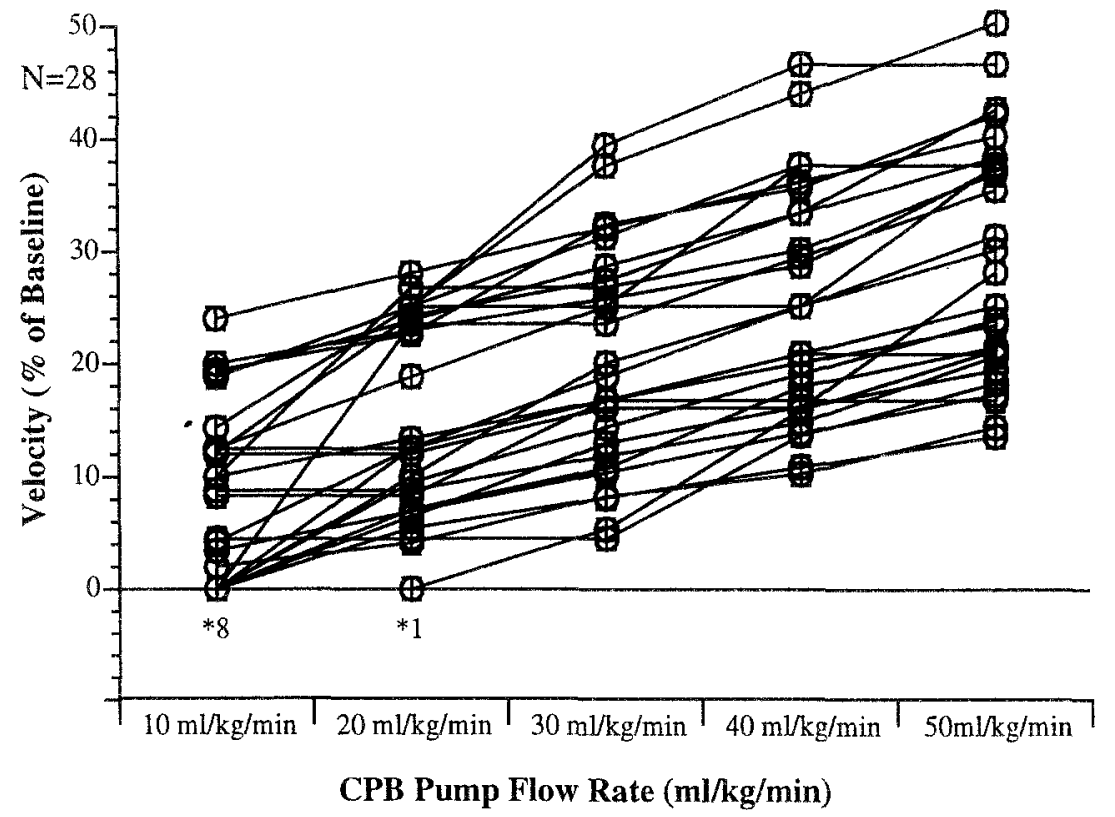

Fig. 1. TCD velocity versus CPB pump flow rate. ${ }^{*}$ Number of patients at selected flow rate with no detectable perfusion.

was $30 \mathrm{ml} / \mathrm{kg}$ per minute, with a possible oxygen debt in the brain resulting in aerobic metabolism if CPB flow rate was maintained at $15 \mathrm{ml} / \mathrm{kg}$ per minute.

In a clinical study by Kern and colleagues, ${ }^{14}$ at deep hypothermic temperatures $\left(18^{\circ} \mathrm{C}\right)$, oxygen debt was calculated to occur between 5 and $30 \mathrm{ml} / \mathrm{kg}$ per minute. On the basis of the relationship between cerebral metabolism and temperature for children undergoing $\mathrm{CPB}$, they were able to predict the minimally acceptable CPB flow rate for a given degree of hypothermia. ${ }^{14,15}$ At $18^{\circ} \mathrm{C}$ they predicted a minimal pump flow rate of $11 \mathrm{ml} / \mathrm{kg}$ per minute.

It is difficult to extrapolate animal data and CPB flow rate because CPB pump flows can be expressed on the basis of weight or body surface area. Equivalent flow rates based on kilograms may not be the same between animal species. In the study by Swain and associates, ${ }^{7}$ sheep were used and the minimal flow of $10 \mathrm{ml} / \mathrm{kg}$ per minute was reported. This corresponds to a surface area-based flow of 0.3 $\mathrm{L} / \mathrm{min}$ per square meter. In the study by Fox, Blackstone, and Kirklin, ${ }^{12}$ monkeys were used and flow was reported on the basis of body surface area. A flow of $0.5 \mathrm{~L} / \mathrm{min}$ per square meter was reported as the minimal flow rate. In the clinical study by Kern and colleagues, ${ }^{14}$ their calculation of $11 \mathrm{ml} / \mathrm{kg}$ per minute as a minimal flow rate corresponds to approximately $0.14 \mathrm{~L} / \mathrm{min}$ per square meter in a $3 \mathrm{~kg}$ neonate. In our study, CPB pump flows are based on weight. Since all of our patients were similar in height and weight, CPB pump flows based on calculated body surface area are reported in Table III.

These previous studies suggest that the acceptable low flow rate for CPB at $15^{\circ} \mathrm{C}$ to $20^{\circ} \mathrm{C}$ is somewhere between 10 and $50 \mathrm{ml} / \mathrm{kg}$ per minute or 0.14 to 0.8 $\mathrm{L} / \mathrm{min}$ per square meter, depending on the species, for cerebral metabolic needs. However, none of these studies attempted to find a CPB flow rate threshold for detectable perfusion in neonates undergoing cardiac operations.

Implicit in the successful use of low-flow CPB, rather than DHCA, to minimize neurologic injury is the assumption that global cerebral perfusion will be present in all patients at a given level of low-flow CPB. Taylor, Burrows, and Bissonnette ${ }^{11}$ suggest that this assumption may not be correct at all levels of low flow. This is supported by our findings in this study. In contrast, Jonassen, Quaegebeur, and Young ${ }^{10}$ reported detectable cerebral perfusion in the MCA by TCD in 16 patients whose ages ranged from 1 day to 9 years at pump flow rates in the range of 25 to $50 \mathrm{ml} / \mathrm{kg}$ per minute, but actual pump flow rates were not reported. In our patients, $71.4 \%$ demonstrated detectable MCA perfusion at 10 $\mathrm{ml} / \mathrm{kg}$ per minute, whereas $28.6 \%$ did not. Jonassen's group ${ }^{10}$ reported detectable MCA perfusion at $25 \mathrm{ml} / \mathrm{kg}$ per minute or greater in all of a similar 


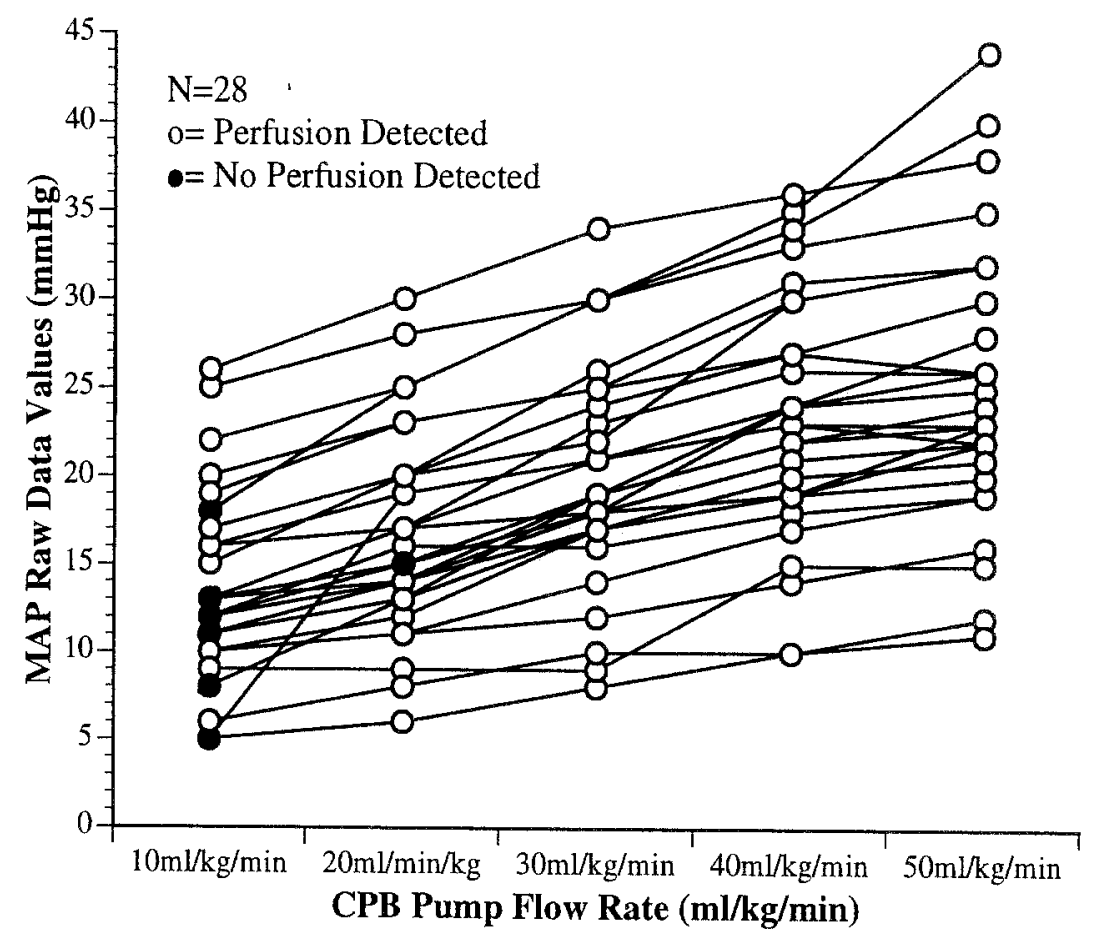

Fig. 2. MAP versus CPB pump flow rate.

number of patients, but their observations were limited to velocities of $3 \mathrm{~cm} / \mathrm{sec}$ or greater. In the cases reported by Taylor, Burrows, and Bissonnette, ${ }^{11}$ an absence of detectable perfusion was seen in a substantial number of patients during low-flow CPB when a TCD instrument with low-pass filters requiring a minimum of $6 \mathrm{~cm} / \mathrm{sec}$ for flow detection was used. In our study, $28.6 \%$ of patients had MCA flow velocities below this threshold of $6 \mathrm{~cm} / \mathrm{sec}$ even at our "standard" low flow rate of $50 \mathrm{ml} / \mathrm{kg}$ per minute. With no low-pass filter in our TCD apparatus, we could reliably detect a mean flow velocity down to $1 \mathrm{~cm} / \mathrm{sec}$ without any increase in background noise. When no perfusion was detected, it is unclear whether there was no cerebral perfusion or whether the limits of detection by our apparatus had been exceeded.

Use of TCD techniques to detect the presence of flow and flow velocity in the MCA during low-flow CPB provides useful real-time clinical information about cerebral perfusion. However, the technique provides information only about flow in the large cerebral arteries being interrogated and cannot necessarily be extrapolated to perfusion throughout the microcirculation, even in areas supplied by the specific vessel being interrogated. Watershed areas supplied by that vessel or microcirculatory flow in areas supplied by other great vessels of the brain might still be compromised in the presence of TCD-detectable flow in the MCA, particularly at low levels of CPB flow and arterial pressure. Under conditions of deep hypothermic CPB in the human infant brain, little is known about the relationship between the presence of low-velocity flow in the MCA and perfusion in the distal microcirculation supplied by it or about the relationship between the presence of MCA flow and flow in other major cerebral arteries and perfusion in their microcirculatory beds. Although absence of TCD-detectable perfusion in the MCA is probably a good indicator of cerebral ischemia, presence of TCD-detectable perfusion in the MCA does not assure perfusion either in all parts of the MCA microcirculation or in areas supplied by other major cerebral arteries. Other modalities such as two-dimensional TCD, which provides a picture of flow in the entire circle of Willis and its associated vessels, are needed to provide a better idea of cerebral perfusion throughout the brain during periods of low-flow CPB and hypothermia. In our study alpha-stat $\mathrm{pH}$ management was used. More recent clinical ${ }^{16}$ and laboratory studies ${ }^{17}$ support the use of $\mathrm{pH}$-stat strategy for DHCA in neonates and infants. It is probable that the $\mathrm{pH}$-stat strategy is associated with a lower 


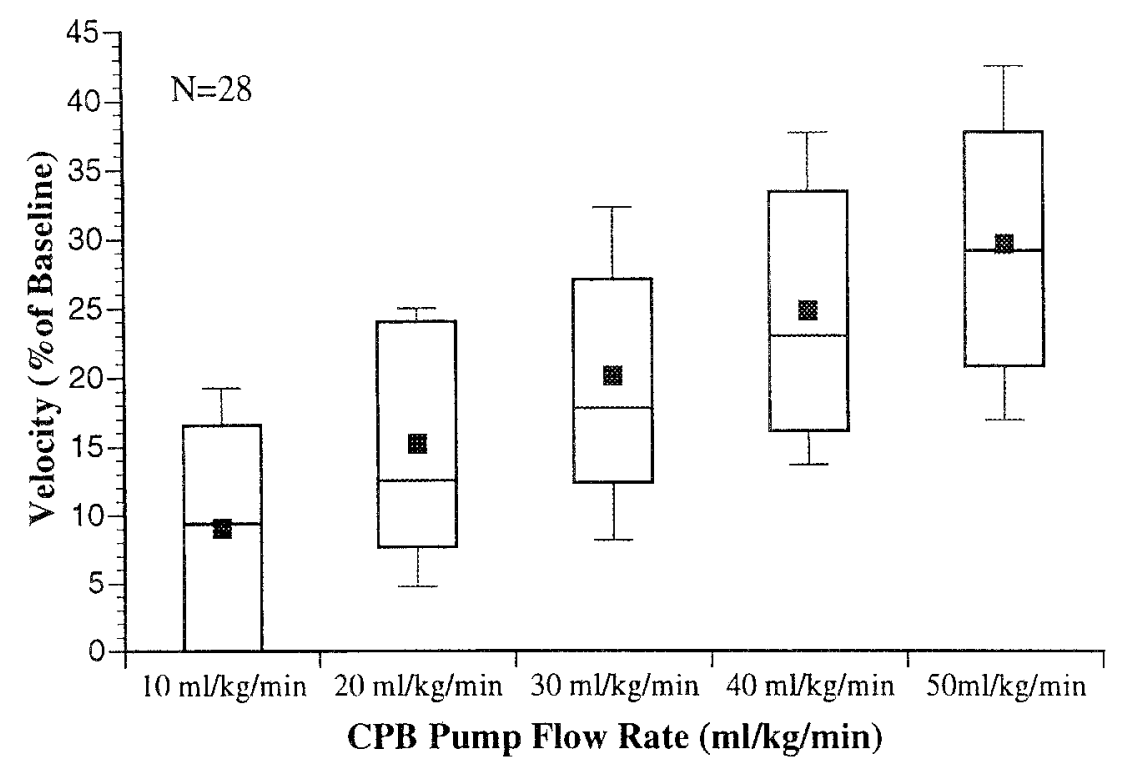

Fig. 3. Box plot of TCD velocity versus CPB pump flow rate.

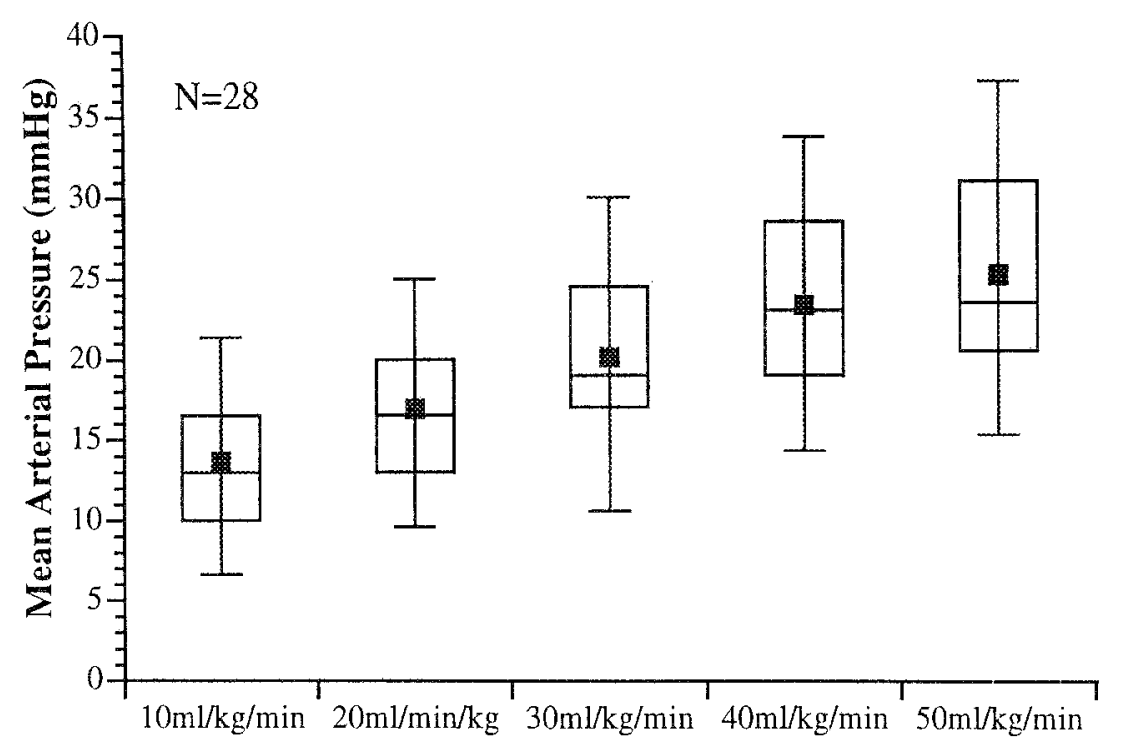

CPB Pump Flow Rate (ml/kg/min)

Fig. 4. Box plot of MAP versus CPB pump flow rate.

perfusion pressure for minimally detectable cerebral artery blood flow. ${ }^{18}$

In conclusion, our data demonstrate that although MCA perfusion can be detected by TCD in neonates at a CPB flow rate of $10 \mathrm{ml} / \mathrm{kg}$ per minute, the presence of MCA perfusion at such low CPB flow rates is not reliable. These data suggest that because of variability in systemic vascular resistance, intracranial pressure, arterial pressure, and jugular ve- nous pressures, the margin of safety represented by a minimum flow of $30 \mathrm{ml} / \mathrm{kg}$ per minute is required to reliably assure the presence of detectable MCA perfusion in all neonates. Even though we detected cerebral perfusion in all patients with pump flows of $30 \mathrm{ml} / \mathrm{kg}$ per minute or higher, this flow cannot be presumed adequate to meet oxygen demand and metabolic needs. On the contrary, flow rates less than $30 \mathrm{ml} / \mathrm{kg}$ per minute did not show detectable 
perfusion in the MCA in all of our patients, but these lower flow rates may provide some advantages over DHCA in patients in whom MCA flow is present. These low flow rates may prevent stagnation of the microcirculation and may provide suffcient oxygen to maintain cellular metabolism in many patients, but may not provide such benefits in those patients in whom flow cannot be detected by TCD. Additional investigations are clearly needed to define better the relationship between low levels of flow in the major cerebral arteries and their metabolic and functional effects in the brain during hypothermic low-flow CPB.

\section{REFERENCES}

1. Ferry PC. Neurological sequelae of cardiac surgery in children. Arch Pediatr Adolesc Med 1987;141:309-12.

2. Ferry PC. Neurological sequelae of open-heart surgery in children: an "irritating question." Arch Pediatr Adolesc Med 1990;144:369-73.

3. Bellinger DC, Wernovsky G, Rappaport LA, Mayer JE, Castaneda AR, Farrell DM, et al. Cognitive development of children following early repair of transposition of the great arteries using deep hypothermic circulatory arrest. Pediatrics 1991;87:701-7.

4. Wical BS, Tomasi LG. A distinctive neurologic syndrome after induced profound hypothermia. Pediatr Neurol 1990;6:202-5.

5. Newburger JW, Jonas RA, Wernovsky G, Wypij D, Hickey PR, Kuban KCK, et al. A comparison of the perioperative neurologic effects of hypothermic circulatory arrest versus low-flow cardiopulmonary bypass in infant heart surgery. N Engl J Med 1993;329:1057-64.

6. Bellinger DC, Jonas RA, Rappaport LA, Wypij D, Wernovsky G, Kuban KCK, et al. Developmental and neurologic status of children after heart surgery with hypothermic circulatory arrest or low-flow cardiopulmonary bypass. N Engl J Med 1995;332:549-55.

7. Swain JA, McDonald TJ Jr, Griffith PK, Balaban RS, Clark RE, Ceckler T. Low-flow hypothermic cardiopulmonary bypass protects the brain. J Thorac Cardiovasc Surg 1991;102:76-84.
8. Bishop CCR, Powell S, Rutt D, Browse NL. Transcranial Doppler measurement of middle cerebral artery flow velocity: a validation study. Stroke 1986;17:913-5.

9. Lindegaard KF, Lundar T, Wiberg J, Sjöberg D, Aaslid R, Nornes $\mathrm{H}$. Variations in middle cerebral artery blood flow investigated with noninvasive transcranial blood velocity measurements. Stroke 1987;18:1025-30.

10. Jonassen AE, Quaegebeur JM, Young WL. Cerebral blood flow velocity in pediatric patients is reduced after cardiopulmonary bypass with profound hypothermia. J Thorac Cardiovasc Surg 1995;110:934-43.

11. Taylor RH, Burrows FA, Bissonnette B. No flow during low-flow cardiopulmonary bypass [letter]. J Thorac Cardiovase Surg 1991;101:363-5.

12. Fox LS, Blackstone RH, Kirklin JW. Relationship of brain blood flow and oxygen consumption to perfusion flow rate during profoundly hypothermic cardiopulmonary bypass. J Thorac Cardiovasc Surg 1984;87:658-64.

13. Miyamoto K, Kawashima Y, Matsuda H, Okuda A, Maeda S, Hirose H. Optimal perfusion flow rate for the brain during deep hypothermic cardiopulmonary bypass at $20^{\circ} \mathrm{C}$. J Thorac Cardiovasc Surg 1986;92:1065-70.

14. Kern FH, Ungerleider RM, Reves JG, Quill T, Smith LR, Baldwin B, et al. Effect of altering pump flow rate on cerebral blood flow and metabolism in infants and children. Ann Thorac Surg 1993;56:1366-72.

15. Greeley WJ, Kern FH, Ungerleider RM, Boyd JL III, Quill TJ, Smith LR, et al. The effect of hypothermic cardiopulmonary bypass and total circulatory arrest on cerebral metabolism in neonates, infants, and children. J Thorac Cardiovasc Surg 1991;101:783-94.

16. Jonas RA, Bellinger DC, Rappaport LA, Wernovsky G, Hickey PR, Farrell DM, et al. Relation of $\mathrm{pH}$ strategy and developmental outcome after hypothermic circulatory arrest. J Thorac Cardiovasc Surg 1993;106:362-8.

17. Hiramatsu T, Miura T, Forbess JM, Du Plessis A, Aoki M, Nomura F, et al. pH strategies and cerebral energetics before and after circulatory arrest. J Thorac Cardiovasc Surg 1995; 109:948-57; discussion 957-8.

18. Burrows FA, Jonas RA, Hickey PR. Acid-base management alters cerebral perfusion during cardiopulmonary bypass [abstract]. Anesthesiology 1994;81:A1398. 